\title{
PERANAN AUDIT INTERNAL DALAM PENGENDALIAN RISIKO PEMBIAYAAN DI BANK BRI SYARIAH KANTOR CABANG DIPONEGORO SURABAYA
}

\author{
Ismatul Khayati \\ Mahasiswa Alumni FEBI UIN SA Surabaya | ismatulK@ gmail.com
}

Abtract: The study, entitled "The Role of Internal Audit in Risk Control Financing Bank BRI Syariah Branch Office Diponegoro Surabaya" This is the result of a qualitative study aimed to answer the question of how the internal audit mechanisms in financing and how the role of internal audit in controlling risks in the financing of Bank BRI Syariah O fice Diponegoro Surabaya branch.

The methodology used in this study is a qualitative method case study on the object under study. Data collection was conducted research by interviewing informants internal audit team and employees of Bank BRI Syariah Branch O ffice Diponegoro Surabaya. The data is then analyzed by inductively mindset which means mindset that is grounded in the facts are specific, then studied, analyzed and summarized into solving the problems or solutions that can be applied generally.

The results showed that, the internal audit mechanism in finance at Bank BRI Syariah Branch Office Diponegoro Surabaya include audit preparation phase, the phase of the audit program, the stage of implementation of audit, audit reporting stage, the stage of follow-up results of the audit and the stage of documentation and administration, and second, the role of internal audit in controlling the financing risks are classified in the role of problem solver, compliance role, the role of negotiator and the role that such controls contained in the audit report.

On the mechanism of internal audit, the auditor should prepare in advance of key risk mitigation data based

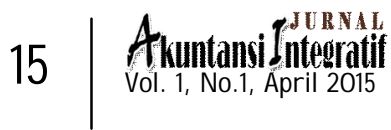


financing, taking samples financing completed in financing the collectability of 3 to 5 and propagated back to the financing Collectable 1 and 2. To that end, each bank can increase the audit team for more funding audited, so that a more comprehensive risk control on all funding channeled bank. In the role of internal audit, internal audit will be instrumental if the creditor or LHA written more specific recommendations for the auditee to improve their performance. So that the internal audit more direct role in the change of attitude of the auditee in carrying out the responsibilities and authority.

Keywords: the role of internal audit, risk management, risk financing 


\section{Pendahuluan}

Pembiayaan merupakan operasional perbankan syariah yang dapat ikut memajukan kesejahteraan ekonomi. Pembiayaan yang disalurkan bank yang dapat digunakan untuk keperluan konsumsi, investasi maupun modal kerja ini melancarkan perputaran kegiatan ekonomi antara produksi dan konsumsi. Namun, pembiayaan ini senantiasa dihadapkan pada risiko-risiko sebagaimana tertera dalam Undang-Undang Nomor 10 Tahun 1998 tentang Perbankan dan dalam Penjelasan Pasal 37 Undang-Undang No. 21 Tahun 2008 tentang Perbankan Syariah menjelaskan bahwa pembiayaan berdasarkan prinsip syariah yang diberikan oleh bank mengandung risiko, sehingga dalam pelaksanaannya bank harus memperhatikan asas-asas maupun pembiayaan berdasarkan prinsip syariah yang sehat. ${ }^{1}$

Bank yang tidak memperhatikan asas-asas pembiayaan yang sehat dalam menyalurkan pembiayaannya, akan terkena berbagai risiko yang harus ditanggungnya antara lain; utang/kewajiban pokok pembiayaan tidak dibayar, margin bagi hasilfee tidak dibayar, membengkaknya biaya yang dikeluarkan dan turunnya kesehatan pembiayaan (finance soundness). Risiko-risiko tersebut dapat mengakibatkan timbulnya pembiayaan bermasalah (Non Performing Financing,NPF) yang dapat disebabkan oleh faktor ekstern maupun intern bank. ${ }^{2}$

Bank BRI Syariah dalam laporan keuangannya menunjukkan adanya risiko pembiayaan dari tingkat pembiayaan bermasalah (NPF) pada tahun 2013 sebesar 3,26\%. ${ }^{3}$ Angka tersebut menunjukkan bank berada di peringkat dua

\footnotetext{
${ }^{1}$ Undang-Undang Republik Indonesia N omor 6 Tahun 2009 tentang Bank Indonesia dan Undang-Undang Republik Indonesia Nomor 21 Tahun 2008 tentang Perbankan Syariah (Bandung: Citra U mbara, 2013)

${ }^{2}$ Faturrahman Djamil, Penyelesaian Pembiayaan Bermasalah di Bank Syariah (Jakarta: Sinar Grafika, 2012), 72-73.

3 BRI Syariah, "Laporan Tahunan 2013", dalam http://www. brisyariah.co.id/sites/default/files/laporantahunan/Laporan\% 20Tahunan\%202013 .pdf, "diakses pada" 310 kto ber 2014.
}

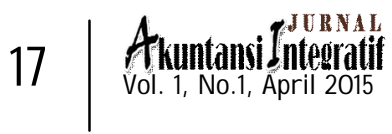


dalam penilaian kesehatannya. Bank BRI Syariah Kantor Cabang Diponegoro Surabaya pada tahun 2013 memiliki tingkat NPF di kisaran 5\%, yang mana menunjukkan bank ini juga masih menghadapi risiko pembiayaan-pembiayaan yang bermasalah.

Tindak lanjut bank dalam menelusuri, menilai dan mengevaluasi risiko pembiayaan tersebut yaitu harus menerapkan fungsi pengawasan pembiayaan yang bersifat menyeluruh (multi layers control), dengan tiga prinsip utama, yaitu; prinsip pencegahan dini (early warning system), prinsip pengawasan melekat (built in control) dan prinsip pemeriksaan internal (internal audit) oleh audit internal sebagai wujud pengendalian risiko kepatuhan demi pengelolaan manajemen risiko yang baik.

Penerapan manajemen risiko sangat diperlukan karena bank berada dalam bisnis berisiko tinggi, di mana bank dalam menjalankan usahanya melakukan penawaran jasa-jasa keuangan, bank juga harus mengambil atau menerima dan mengelola berbagai jenis risiko keuangan secara efektif agar dampak negatifnya tidak terjadi. Oleh karena itu, agar terciptanya kondisi bank yang sehat dan baik maka perlu diterapkannya manajemen risiko dengan melakukan audit yang dilaksanakan oleh auditor internal.

Salah satu kasus yang ditemukan auditor pembiayaan menyebutkan adanya kasus berupa side streaming yang disebabkan oleh lemahnya monitoring pasca pembiayaan, sehingga penggunaan dana pembiayaan tidak sesuai dengan tujuan awal pembiayaan. ${ }^{4}$ Terjadinya kasus pada pembiayaan tersebut, maka bank perlu mendapat perhatian lebih pada keberadaan audit internal terutama pada bidang pembiayaan. Audit internal pembiayaan bertanggung jawab pada pengendalian risiko-risiko yang dapat menjadikan pembiayaan bermasalah. Dalam menemukan kasus-kasus seperti pada

\footnotetext{
4 Made Dharmawan, "Kertas Kerja Pemeriksaan Auditor (KKPA) Bidang Pembiayaan", D okumen Pribadi, D esember 2013.
} 
pembiayaan tersebut, audit internal tidak jarang akan langsung menginterogasi pegawai bank bagian pembiayaan maupun melihat langsung kondisi nasabah. Setelah mendatangi pihak bank dan nasabah pembiayaan yang bermasalah, audit internal melakukan penilaian, evaluasi hasil dan memberikan masukan komentar pada manajemen bank perihal tindakan apa yang perlu dilakukan. ${ }^{5}$

Posisi audit internal ini menjadi penting sebagaimana fungsi dan tanggung jawabnya dalam mengevaluasi pembiayaan yang disalurkan agar tidak menjadi bermasalah hingga merugikan bank. Penelitian ini mengambil objek pada Bank BRI Syariah Kantor Cabang Surabaya yang membawahi beberapa Kantor Cabang Pembantu di wilayah Jawa Timur. Untuk mengetahui bagaimana porsi audit internal dalam mengendalikan risiko pembiayaan di bank tersebut, yang mana dalam tiga tahun terakhir ini juga mengalami penurunan NPF.

Penelitian ini diadakan untuk menjawab dua permasalahan yaitu bagaimana mekanisme audit internal pembiayaan dan bagaimana peranan audit internal dalam mengendalikan risiko pembiayaan di Bank BRI Syariah Kantor Cabang Surabaya. Untuk menjawab dua permasalahan tersebut digunakan metode penelitian kualitatif dengan jenis penelitian studi kasus pada objek yang diteliti. Pengumpulan data penelitian dilakukan dengan wawancara kepada informan yaitu tim audit internal dan pegawai Bank BRI Syariah Kantor Cabang Diponegoro Surabaya serta berdasarkan dokumen bank dan literatur yang mendukung.

\section{Risiko Pembiayaan dan Audit Internal}

Pembiayaan atau financing dapat diartikan sebagai pendanaan yang diberikan oleh suatu pihak kepada pihak lain untuk mendukung investasi yang telah direncanakan, baik dilakukan sendiri maupun lembaga. ${ }^{6}$ Pembiayaan yang

\footnotetext{
${ }^{5} \mathrm{lbid}$.

${ }^{6}$ Veithzal Rivai dan Arviyan Arifin, Islamic Banking (Jakarta: Bumi Aksara, 2010), 681.
}

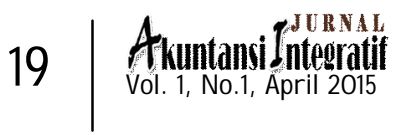


disalurkan bank syariah mempunyai karakteristik sendirisendiri, tergantung masing-masing bank. Namun secara umum dari produk pembiayaan, pelaksana pembiayaan, proses pemberian pembiayaan dan ketentuan tingkat kolektibilitas pembiayaannya tidak jauh berbeda antara bank syariah yang satu dengan lainnya. Secara garis besar, produk pembiayaan bank syariah terbagi ke dalam tiga kategori yang dibedakan berdasarkan tujuan penggunaannya, yaitu pembiayaan dengan prinsip jual beli (Bai') yang terdiri dari pembiayaan mura $>$ bah $\} a h$, sala $>m$ dan istithna', pembiayaan dengan prinsip sewa (Ija>rah) yaitu transaksi yang dilandasi adanya perpindahan manfaat, dan pembiayaan dengan prinsip bagi hasil (Shirkah) yang terdiri dari pembiayaan musharakah dan pembiayaan mud\}a>rabah. ${ }^{7}$

Pada umumnya, pembiayaan dilaksanakan oleh bagian pemasaran. ${ }^{8}$ Sedikitnya ada empat petugas yang menjalankan aktivitas pembiayaan pada bank syariah, mulai dari petugas yang menawarkan produk bank syari'ah sampai pada petugas yang menangani pembiayaan, yaitu Account Officer (A/O), Unit Support Pembiayaan, Unit Administrasi Pembiayaan dan Unit Pengawasan Pembiayaan. Pelaksanaan kinerja para pelaksana pembiayaan meliputi proses pemberian pembiayaan dari pengajuan hingga pencairan. Proses pemberian pembiayaan ini merupakan suatu rangkaian yang bersifat end to end yang dimulai dari tahap inisiasi, tahap analisis pembiayaan, tahap pemutusan pembiayaan, tahap pencairan, tahap monitoring dan tahap penyelesaian atau restrukturisasi jika pembiayaan menjadi bermasalah. Kesemua tahapan ini harus dilaksanakan berdasar aturan prosedur yang berlaku. Apabila ada proses pemberian pembiayaan yang tidak sesuai dengan prosedur yang sebenarnya, pembiayaan tersebut berpotensi mengalami permasalahan yang tergambar dalam penggolongan kolektibilitas pembiayaan.

\footnotetext{
${ }^{7}$ Adiwarman A. Karim, Bank Islam: Analisis Fiqih dan Keuangan (Jakarta: PT RajaG rafindo Persada, 2011), 98.

${ }^{8}$ Veithzal Rivai dan Arviyan Arifin, Islamic Banking, 696.
} 
Kolektibilitas (collectibility) yaitu keadaan pembayaran pokok atau angsuran pokok dan bagi hasil oleh nasabah serta tingkat kemungkinan diterimanya kembali dana yang ditanamkan dalam surat-surat berharga atau penanaman lainnya (pembiayaan) berdasarkan ketentuan Bank Indonesia. ${ }^{9}$ Kolektibilitas dari suatu pembiayaan yang disalurkan dapat dikelompokan dalam lima kelompok, yaitu pembiayaan lancar, dalam perhatian khusus, kurang lancar, diragukan dan macet. Semakin mendekatinya pembiayaan pada kategori macet, maka semakin menunjukkan pembiayaan tersebut berisiko merugikan bank dan kondis bank yang tidak sehat.

Menurut Bank Indonesia, risiko perbankan merupakan suatu kejadian potensial baik yang dapat diperkirakan (expected) maupun yang tidak dapat diperkirakan (unexpected) yang berdampak negatif terhadap pendapatan dan permodalan bank. Risiko yang melekat pada aktivitas perbankan (risiko inheren) terdiri dari risiko pembiayaan, risiko pasar, risiko operasional, risiko likuiditas, risiko kepatuhan, risiko hukum, risiko strategis, risiko reputasi, risiko imbal hasil dan risiko investasi. Untuk menghadapi berbagai macam risiko inheren, maka Bank Indonesia mewajibkan setiap bank umum agar memiliki Pedoman Standar Penerapan Manajemen Risiko dalam SE. BI. No. 13/23/DPNP tanggal 25 Oktober 2011.

Suatu produk atau aktivitas bank dapat mengandung satu atau lebih dari jenis risiko. Karena itu, bank perlu melakukan pengelolaan risiko secara integratif melalui manajemen risiko. Pada hakikatnya manajemen risiko merupakan serangkaian metodologi dan prosedur yang digunakan untuk mengidentifikasi, mengukur, memantau dan mengendalikan risiko yang timbul dari seluruh kegiatan usaha bank. ${ }^{10}$

Di antara risiko yang paling krusial dalam dunia perbankan yaitu risiko pembiayaan. Namun dalam

9 O toritas Jasa Keuangan, "OJK-Pedia", dalam http://www.ojk.go.id/pedia\# tabK, diakses pada 11 Desember 2014.

${ }_{10}$ Ikatan Bankir Indonesia, M emahami Bisnis Bank Syariah (Jakarta: PT Gramedia Pustaka, 2014), 341-342

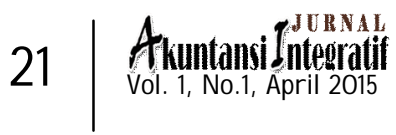


pembiayaan itu sendiri dapat mengandung risiko lain seperti risiko kepatuhan. Risiko pembiayaan adalah risiko kegagalan nasabah untuk memenuhi kewajibannya secara penuh dan tepat waktu sesuai dengan kesepakatan. Risiko ini bisa muncul saat nasabah gagal memenuhi kewajiban untuk membayar pinjamannya secara penuh pada waktu yang telah disepakati maupun akibat ketidakmampuan atau ketidakmauan nasabah untuk memenuhi kewajiban yang tertuang dalam kontrak (akad). ${ }^{11}$ Sedangkan risiko kepatuhan adalah risiko akibat bank tidak mematuhi dan/tidak melaksanakan peraturan perundang-undangan dan ketentuan yang berlaku. Misalnya petugas bank terlambat dalam menyampaikan laporan Sistem Informasi Debitur (SID) kepada Bank Indonesia. ${ }^{12}$

Risiko pembiayaan perbankan syariah biasanya ditunjukkan dari penghitungan tingkat Non Performing Financing (NPF). NPF merupakan ukuran tingkat pembiayaan bermasalah oleh sebab-sebab tertentu. Untuk menentukan langkah yang perlu diambil dalam menghadapi pembiayaan bermasalah ini, terlebih dahulu memang perlu diteliti sebabsebab terjadinya. Apabila pembiayaan bermasalah disebabkan oleh faktor eksternal seperti bencana alam, bank tidak perlu lagi melakukan analisis lebih lanjut melainkan hanya membantu nasabah memperoleh penggantian dari perusahaan asuransi. Sedangkan apabila pembiayaan bermasalah disebabkan oleh faktor internal dalam manajerial bank itu sendiri, meskipun telah dilakukan pengawasan seksama dan tetap timbul pembiayaan bermasalah, maka sedikit banyak terkait dengan kelemahan pengawasannya. ${ }^{13}$

Upaya untuk mengendalikan atau menghindarkan secara dini pembiayaan yang bermasalah, bank syariah sebagai bank umum ikut berpedoman pada SE. No. 27/7NPPB yang

\footnotetext{
${ }^{11}$ Tariqullah Khan dan Habib Ahmed, M anajemen Risiko Lembaga Keuangan Syariah (Jakarta: Bumi Aksara, 2008), 12-13.

${ }^{12}$ Ikatan Bankir Indonesia, Memahami Bisnis Bank Syariah (Jakarta: PT Gramedia Pustaka, 2014),344-345.

${ }^{13}$ Faturrahman Djamil, Penyelesaian Pembiayaan..., 73-74.
} 
menetapkan setiap bank umum agar melakukan penyusunan dan pelaksanaan kebijaksanaan terhadap pembiayaan yang disalurkannya. Salah satu dari pelaksanaan kebijaksanaan tersebut adalah bank harus memiliki pengawasan pembiayaan, mengingat pembiayaan merupakan salah satu kegiatan usaha yang rawan untuk merugikan bank. ${ }^{14}$

Rawannya risiko pada kegiatan bisnis perbankan menuntut bank harus memiliki pengawasan untuk memastikan bahwa operasional bank telah dilaksanakan sesuai ketentuan yang berlaku (auditing) sekaligus memitigasi dan meminimalisasi risiko yang telah terjadi dan/atau akan terjadi sehingga segera mengambil langkah preventif. ${ }^{15}$ Sistem pengendalian intern dimaksudkan juga untuk menjamin dicegahnya terjadi penyalahgunaan wewenang oleh berbagai pihak yang dapat merugikan bank dan terjadinya praktik pemberian pembiayaan yang tidak sehat. Pengendalian intern dalam perbankan dijalankan oleh bidang audit/bank auditor yang memberikan perhatian besar pada penilaian internal control/internal audit bidang pembiayaan apakah telah memadai atau belum. ${ }^{16}$

Audit internal dapat didefinisikan sebagai suatu fungsi penilaian yang independen dalam suatu organisasi untuk menguji dan mengevaluasi kegiatan organisasi yang dilaksanakan. Tujuan audit internal adalah membantu para anggota organisasi agar dapat melaksanakan tanggung jawabnya secara efektif. Untuk itu, audit internal akan melakukan analisis, penilaian, dan mengajukan saran-saran kepada manajemen organisasi dalam pengambilan keputusan. ${ }^{17}$

Agar penjabaran operasional dari misi, kewenangan, independensi dan ruang lingkup pekerjaan audit internal bank terlaksana sesuai dengan yang diharapkan, Bank Indonesia telah menetapkan Standar Pelaksanaan Fungsi Audit Intern

\footnotetext{
14 Teguh Pudjo Muljono, Bank Auditing: Petunjuk Pemeriksaan Intern Bank (Jakarta: Djambatan, 1999), 119.

${ }^{15}$ Ikatan Bankir Indonesia, M emahami Bisnis..., 375.

${ }^{16}$ Teguh Pudjo Muljono, Bank Auditing..., 119.

${ }^{17}$ H iro Tugiman, Standar Profesional Audit Internal (Yogyakarta: PT Kanikus, 2014), 11.
}

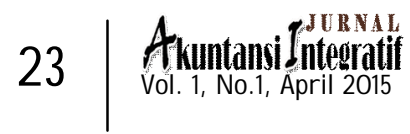


Bank (SPFAIB) sebagai ukuran minimal yang harus dipatuhi oleh semua bank umum di Indonesia. Semua yang ditetapkan dalam SPFAIB itu wajib dilaksanakan oleh semua bank umum. Ketentuan dalam SPFAIB tersebut dilaksanakan oleh Satuan Kerja Audit Intern (SKAI) di masing-masing bank. Satuan kerja ini boleh saja namanya berbeda-beda namun mengandung makna sesuai SPFAIB, misalnya Divisi Audit Intern, Urusan Pemeriksaan Intern, Urusan Audit Intern, Group Audit Intern, dan sebagainya. ${ }^{18}$

Organisasi audit internal yang menjalankan tugasnya sebagai Satuan Kerja Audit Intern (SKAI) suatu bank disesuaikan dengan perkembangan bank itu sendiri dan ditetapkan dengan Surat Keputusan Direksi. SKAI dipimpin langsung oleh Kepala SKAI yang diangkat dan diberhentikan oleh Direktur Utama dengan persetujuan Dewan Audit serta dilaporkan ke Bank Indonesia. Kepala SKAI ini bertanggung jawab kepada Direktur Utama dan dapat berkomunikasi secara langsung dengan Dewan Audit untuk menginformasikan berbagai hal yang berhubungan dengan audit. Adapun kedudukan Dewan Audit itu sendiri dalam konsep SPFAIB harus independen terhadap manajemen bank yang diauditnya. Oleh karena itu, Dewan Audit bertanggung jawab langsung kepada Dewan Komisaris bank.

Adapun untuk fungsi, tanggung jawab, wewenang dan kode etik Dewan Audit Bank diuraikan dalam satu piagam yang disebut dengan Piagam Dewan Audit Charter (Internal Audit Charter). Maksud dari Piagam tersebut adalah untuk memberikan pengertian umum mengenai tujuan dan ruang lingkup tugas-tugas SKAI serta untuk membedakan antara tanggung jawab dan wewenang SKAI dengan manajemen. ${ }^{19}$

Pelaksanaan audit sangat dipengaruhi oleh besarnya organisasi dan karakteristik operasi satuan kerja auditee yang akan diaudit. SPFAIB merinci pelaksanaan audit ini ke dalam

${ }^{18}$ Tjukria P. Tawaf, Audit Intern Bank: Penelaahan serta Petunjuk Pelaksanaannya (Jakarta: Salemba Empat, 1999),16.

${ }^{19}$ bid., 54-59. 
enam tahap kegiatan, yaitu persiapan audit, penyusunan program audit, pelaksanaan penugasan audit, pelaporan Hasil Audit, tindak lanjut Hasil Audit serta dokumentasi dan administrasi.

Semua pihak yang berhubungan dengan operasional perbankan sangat berkepentingan untuk mengetahui, memahami dan memastikan semua temuan berikut permasalahan serta dampak kerugian yang timbul sebagaimana yang tertuang dalam temuan Hasil Audit untuk segera diperbaiki sesuai waktu yang telah menjadi komitmen bersama. Pelaksanaan tindak lanjut hasil audit ini mengharuskan pegawai bank untuk mengetahui prosedur dan proses yang menjadi bidang tugasnya sesuai job description dan wewenang yang dimiliki. Tindakan dan langkah yang harus dilaksanakan untuk menindaklanjuti hasil audit adalah menyusun rencana tindak lanjut hasil audit yang disiapkan tepat waktu sesuai denga rekomendasi audit. ${ }^{20}$

Tugas pokok sebagai auditor intern tersebut harus dilaksanakan secara profesional menurut standar dan prosedur yang telah ditetapkan. Akan tetapi hal tersebut memerlukan proses interaksi dalam pelaksanaannya. Ada beberapa peran yang dapat dibawakan oleh auditor intern di antaranya; pertama, peran sebagai pemecah masalah, di mana auditor intern harus mampu menggunakan metode pemecah masalah yang rasional. Kedua, peran sebagai pemecah konflik karena temuan yang ada dari pelaksanaan audit bisa menjurus pada timbulnya konflik bila seorang auditor kurang mampu untuk menyelesaikannya dengan auditee. Ketiga, peran wawancara yang mana komunikasi yang akan dilakukan oleh Auditor seringkali berbentuk wawancara. Tujuannya adalah mencari fakta dan bukan opini. Karena itu auditor intern harus memahami konteks dan tujuan wawancara itu. Keempat, peran negosiator dan komunikator. Dalam peran negosiator, seseorang dituntut untuk terus menerus mampu menjual

${ }^{20}$ Ikatan Bankir Indonesia, M emahami Bisnis..., 381.

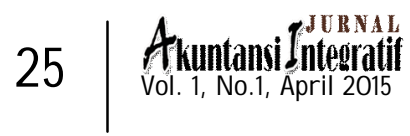


"posisi auditor", program auditor ataupun ide-ide. Negosiator harus berpegang pada sasaran dan berupaya agar hubungan tidak tegang. Negosiator harus berusaha mendapat hasil yang positif dalam setiap proses sesulit apapun kondisinya.

\section{Aplikasi Audit Internal pada Bank BRI Syariah Kantor Cabang Diponegoro Surabaya}

Menurut Tjukria P. Tawaf, audit internal bertanggung jawab kepada Direktur Utama dan dapat berkomunikasi secara langsung dengan Komite Audit untuk menginformasikan berbagai hal yang berhubungan dengan audit. Kedudukan Komite Audit itu sendiri dalam konsep SPFAIB harus independen terhadap manajemen. Oleh karena itu, Komite Audit bertanggung jawab kepada Dewan Komisaris bank. ${ }^{21}$

Bank BRI Syariah secara keseluruhan pada setiap kantor cabangnya, termasuk BRI Syariah Kantor Cabang Diponegoro Surabaya dalam Piagam Auditnya juga dikatakan bahwa terselenggaranya Sistem Pengendalian Intern (SPI) Bank yang handal dan efektif menjadi tanggung jawab semua pihak yang terlibat dalam organisasi bank. Dewan Komisaris (Board of Commisioners) bertanggung jawab melakukan pengawasan terhadap pelaksanaan pengendalian intern secara umum, termasuk kebijakan Direksi yang menetapkan pengendalian tersebut. Direksi (President Director) bertanggung jawab menciptakan dan memelihara SPI yang efektif serta memastikan bahwa sistem tersebut berjalan secara aman dan sehat sesuai tujuan pengendalian intern yang ditetapkan bank. ${ }^{22}$

Satuan Kerja Audit Intern (Audit Internal Group) harus mampu mengevaluasi dan berperan aktif dalam meningkatkan efektivitas SPI yang berkaitan dengan operasional bank yang berpotensi menimbulkan risiko. Sedangkan pejabat dan pegawai bank wajib memahami dan melaksanakan SPI yang efektif dengan mendorong budaya risiko yang memadai dan

\footnotetext{
${ }^{21}$ Tjukria P. Tawaf, Audit Intern Bank...,56.

${ }^{22}$ BRI Syariah, "Satuan Kerja Audit Internal (SKAI)", Piagam Audit (Audit Charter) (Desember, 2009), 2.
} 
mempercepat proses identifikasi praktik perbankan yang tidak sehat. ${ }^{23}$

Di antara pihak-pihak yang berkepentingan dengan SPI yang handal dan efektif adalah Satuan Kerja Audit Intern (SKAI). SKAI merupakan bagian dari sistem internal control perusahaan yang memiliki peranan penting dalam melindungi dan meningkatkan operasional bisnis BRI Syariah. Pengendalian risiko pembiayaan oleh audit internal Bank BRI Syariah Kantor Cabang Surabaya dilakukan dengan memeriksa data-data dan bukti-bukti apakah bank telah melaksanakan analisis pembiayaan secara mendalam sesuai prosedur, pemantauan kemampuan dan kepatuhan debitur serta perkembangan proyek yang dibiayai, penilaian kembali nilai agunan secara berkala sesuai dengan prosedur, penetapan limit yang jelas seluruh fasilitas yang diberikan kepada setiap debitur serta penilaian dan analisis yang mendalam terhadap kemampuan debitur dalam pemberian jaminan. Untuk mendapatkan kepastian bahwa bank telah melakukan kegiatan pengendalian risiko tersebut, audit internal selalu langsung melakukan kunjungan kepada nasabah. Hal ini dilakukan untuk mengklarifikasi dan identifikasi informasi bukti langsung, apakah kondisi persyaratan pembiayaan dalam data sesuai dengan aslinya. ${ }^{24}$

Pengendalian risiko pembiayaan oleh audit internal di Bank BRI Syariah Kantor Cabang Diponegoro Surabaya dilakukan melalui proses pengumpulan dokumen berupa data seluruh pembiayaan yang disalurkannya, dianalisis untuk ditemukan gejala-gejala pembiayaan berisiko, penelusuran informasi dengan menemukan bukti langsung tentang kondisi nasabah pembiayaan hingga membuat Laporan Hasil Audit (LHA). Secara lebih rinci, kegiatan audit internal dalam rangka pengendalian risiko pembiayaan dijelaskan sebagai berikut:

\footnotetext{
${ }^{23} \mathrm{lbid}$., 3.

${ }^{24}$ Ade Irfan, Ketua Tim Audit, Reza dan Made D harmawan, Anggota Tim Audit, Wawancara, Surabaya, 30 N ovember 2014
} 
a. Mengumpulkan data pembiayaan yang disalurkan bank dalam satu tahun, kemudian dilakukan sampling. Sample diambil berdasarkan tingkat risiko terbesar dan berdasar jenis pembiayaannya. Secara keseluruhan data pembiayaan di Bank BRI Syariah Kantor Cabang Diponegoro Surabaya tahun 2013 sebagai dasar pengambilan sampel sebagai berikut:

Tabel 1

Jumlah Pembiayaan Bank BRI Syariah Kantor Cabang

Diponegoro Surabaya tahun $2013^{25}$

\begin{tabular}{|l|l|l|l|l|l|l|}
\hline \multirow{2}{*}{ Jenis Pembiayaan } & \multicolumn{7}{|l|}{ Kolektibilitas } & Jumlah \\
\cline { 2 - 8 } & 1 & 2 & 3 & 4 & 5 & \\
\hline Piutang Murabahah & 18 & - & - & - & - & 18 \\
\hline Piutang Murabahah Mikro & 15 & 4 & 1 & - & 4 & 24 \\
\hline Pembiayaan Musyarakah & 9 & - & - & - & - & 9 \\
\hline $\begin{array}{l}\text { Pembiayaan Modal Kerja } \\
\text { Revolving }\end{array}$ & 4 & - & - & - & - & 4 \\
\hline Pembiayaan Mudharabah & 5 & - & - & - & - & 5 \\
\hline
\end{tabular}

Sumber: Data Diolah, "Pembiayaan Bank BRI Syariah Kantor Cabang Diponegoro Surabaya", 2013

Data kumpulan pembiayaan pada tabel 3.1 di atas diklasifikasikan berdasar jenis pembiayaan untuk lebih dikenali jenis risikonya dan berdasar kolektibilitasnya untuk mengetahui tingkat risikonya. Data tersebut diperoleh auditor dari kantor pusat dan untuk efisiensi akan dilakukan sampel nasabah mana yang lebih dahulu diaudit

b. Menganalisis permasalahan dalam pembiayaan dengan cara menyesuaikan data penyaluran pembiayaan dengan prosedur yang benar

c. Apabila ditemukan kejanggalan atas data/persyaratan nasabah dalam penerimaan pembiayaannya, auditor akan melakukan kunjungan langsung kepada nasabah

\footnotetext{
${ }^{25}$ Made D harmawan, "Pembiayaan Bank BRI Syariah Kantor Cabang D iponegoro Surabaya", D okumen Pribadi, Desember 2013
} 
d. Menemukan informasi berupa bukti-bukti keadaan nasabah yang dikunjungi, disesuaikan dengan data penyaluran pembiayaan bank terhadap nasabah tersebut. Diantara indikasi yang akan dijadikan bukti temuan audit antara lain tempat usaha, usaha yang fiktif, kepemilikan usaha maupun kondisi agunannya

e. Membuat Kertas Kerja Pemeriksaan Audit yang berisi temuan-temuan audit berupa kondisi nasabah, kelemahan/kesalahan prosedur, kriteria/aturan yang dilanggar, penyebab, dampak, rekomendasi evaluasi dari auditor kepada auditee (bank) serta komentar auditee untuk perbaikan. KKPA ini dibuat untuk setiap temuan nasabah. ${ }^{26}$ Contoh beberapa temuan kasus pembiayaan yang tertulis dalam KKPA tahun 2013 di Bank BRI Syariah Kantor Cabang Surabaya yaitu:

1) Temuan (Risk Issue) Penggunaan Dana Pembiayaan Tidak Sesuai Dengan Tujuan Semula (Side Streaming)

Berdasarkan penelusuran auditor, kasus ini disebabkan oleh lemahnya monitoring pasca pembiayaan sehingga penggunaan dana pembiayaan tidak sesuai dengan tujuan awal. Ditemukan juga fakta terdapat pelanggaran Syariah Compliance, di mana tidak ditemukan buktikwitansi atas renovasi tempat usaha dan tidak ditemukan laporan kunjungan Relation Officer (RO). Hal ini terjadi dikarenakan petugas kurang mendalam dalam hal analisa awal atas kebutuhan pembiayaan nasabah. Sehingga akan berdampak pada nasabah yang menggunakan dana hasil pencairan pembiayaan tidak sesuai dengan tujuan pembiayaan. Bank juga masuk ke dalam posisi lemah yang disebabkan karena tidak diketahuinya secara pasti kegunaan dana pembiayaan akibat Side Streaming yang dilakukan oleh nasabah. Dalam hal ini, auditor dapat memberi

${ }^{26}$ Made D harmawan, Anggota Tim Audit, Wawancara, Surabaya, 15 N ovember 2014, Ade Irfan, Kepala Tim Audit dan Reza, Anggota Tim Audit, Wawancara, Surabaya, 11 Desember 2014

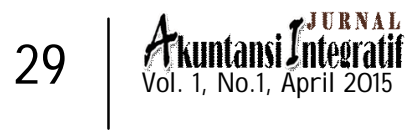


rekomendasi/pesan atas kasus tersebut agar untuk selanjutnya RO lebih ketat dalam melakukan monitoring kepada nasabah terutama pasca pencairan. Petugas bank juga lebih memperhatikan persyaratan pembiayaan pada proses inisiasi sehingga analisa pembiayaan yang diajukan sudah benar dan wajar.

2) Temuan (Risk Issue) Overfinancing Pemberian Pembiayaan

Kasus kedua ini menurut pemeriksaan auditor disebabkan karena overfinancing pemberian pembiayaan, pemberian pembiayaan yang ternyata untuk tujuan spekulatif, lemahnya monitoring pasca pembiayaan sehingga penggunaan dana pembiayaan tidak sesuai dengan tujuan awal dan tidak dipenuhi persyaratan dalam penilaian jaminan. Hal ini terjadi sebagaimana kasus pertama yaitu petugas kurang mendalam dalam hal analisa awal atas kebutuhan pembiayaan nasabah. Dampak dari kasus ini adalah bank memberikan fasilitas pembiayaan lebih besar dari pada kebutuhan nasabah, nasabah menggunakan dana pembiayaan tidak sesuai dengan tujuan dan bank masuk ke dalam posisi yang lemah disebabkan tidak diketahuinya kegunaan dana pembiayaan nasabah. Untuk menanggulanginya, auditor merekomendasikan untuk selanjutnya $\mathrm{RO}$ lebih ketat dalam melakukan monitoring kepada nasabah terutama pasca pencairan dan UFO lebih memperhatikan persyaratan pembiayaan pada proses inisiasi sehingga analisa pembiayaan yang diajukan sudah benar dan wajar. ${ }^{27}$

Temuan kasus tersebut merupakan intisari dari isi dari KKPA yang selalu disusun oleh auditor setelah melakukan pemeriksaan langsung di lapangan. Hasil pemeriksaan audit internal tersebut diberikan kepada

27 Made Dharmawan, "Kertas Kerja Pemeriksaan Auditor (KKPA) Bidang Pembiayaan", D okumen Pribadi, Desember 2013 
auditee untuk diisi tanggapan, rencana tindak lanjut, target penyelesaian dan realisasi rencana tindak lanjut auditee. Kemudian diserahkan ke auditor lagi untuk dilaporkan kepada Direksi.

f. Setiap KKPA tersebut dikumpulkan oleh auditor dalam satu file Laporan Hasil Audit (LHA) yang disusun berdasarkan temuan Major dan Moderat. Temuan Major yaitu temuan yang berisiko tinggi atau temuan dengan kesalahan yang dapat merugikan bank. Sedangkan temuan moderat yaitu temuan dengan kesalahan ringan. Sebelumnya LHA ini dibuat setelah temuan-temuan tersebut dikonfirmasi dengan auditee dan didiskusikan dengan kepala tim audit. Setelah itu, LHA diserahkan kepada Audit Group Head (AGH), Direktur Utama Bank BRI Syariah dan Auditee Kantor Cabang yang bersangkutan.

Berdasarkan LHA yang diserahkan auditor kepada Kepala Audit dan kemudian kepada Direksi, Bank BRI Syariah Kantor Pusat terbantu untuk mengetahui ketika terdapat pembiayaan bermasalah. Tindak lanjut hasil audit oleh Bank BRI Syariah atas temuan audit berupa pembiayaan yang bermasalah tersebut dilakukan dalam dua tahap. Pertama, hasil audit ditindaklanjuti oleh Tim Pencari Fakta (TPF) untuk klarifikasi temuan audit dengan auditee bank yang bersangkutan (dalam hal ini Bank BRI Syariah Kantor Cabang Diponegoro Surabaya). Kedua, hasil audit ditindaklanjuti oleh auditee untuk bahan perbaikan (restrukturisasi atau rescheduling) setelah diklarifikasi bersama TPF. Temuan audit dalam LHA juga dapat menjadi pertimbangan Direktur Utama Bank BRI Syariah dalam menindaklanjuti kinerja auditee yang bersangkutan. ${ }^{28}$

Audit internal memang mempunyai peran yang sangat penting dalam setiap operasional perbankan. Pada kasus pembiayaan, ketika petugas pembiayaan dituntut untuk

${ }^{28}$ Made Dharmawan, Anggota Tim Audit,W awancara, Surabaya, 13 N ovember 2014; Ade Irfan, Ketua Tim Audit, Wawancara, Surabaya, 02 Desember 2014; Reza dan Bowo, Anggota Tim Audit, W awancara, Surabaya, 02 D esember 2014.

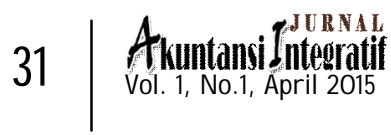


mendapatkan sejumlah pembiayaan berdasarkan target yang ditetapkan Manajernya, disisi lain ia juga harus menjaga agar pembiayaan yang didapatkannya harus sesuai denga aturan yang berlaku. Petugas pembiayaan berpotensi sekali menimbulkan risiko pembiayaan seperti tetap menerima pembiayaan dengan cara-cara yang di luar prosedur agar ia dapat mencapai target pembiayaannya. ${ }^{29}$

Maka dari itu, dalam rangka mengendalikan risiko pembiayaan tersebut, audit internal memantau kinerja petugas pembiayaan agar pembiayaan disalurkan sesuai prosedur dan tidak menyebabkan pembiayaan bermasalah. Di antara hal-hal yang dilakukan audit dalam pengendalian risiko pada prosedur penyaluran pembiayaan oleh auditee Bank BRI Syariah Kantor Cabang Diponegoro Surabaya sebagai berikut:

1. Pemeriksaan atas pengajuan permohonan dan data nasabah pembiayaan

Audit internal pembiayaan memeriksa dokumen yang menjadi syarat-syarat pengajuan pembiayaan seperti profil debitur, tempat usaha debitur, surat permohonan pembiayaan, kepemilikan agunan dan legalitas usaha serta memeriksa keasliannya. Dalam pemeriksaan ini auditor Bank BRI Syariah dapat melakukan kunjungan langsung di tempat debitur.

2. Pemeriksaan atas analisis pembiayaan

Audit internal pembiayaan memeriksa kembali kebenaran dan kelengkapan analisis pembiayaan yang telah dilakukan auditee (Bank BRI Syariah Kantor Cabang Diponegoro Surabaya) berdasar prosedurnya.

3. Pemeriksaan atas keputusan pembiayaan

Audit internal pembiayaan memeriksa hasil verifikasi SBM dan UFO Bank BRI Syariah Kantor Cabang Diponegoro Surabaya dalam menyetujui permohonan pembiayaan

${ }^{29}$ Made Dharmawan, Anggota Tim Audit,Wawancara, Surabaya, 13 N ovember 2014; Ade Irfan, Ketua Tim Audit, Wawancara, Surabaya, 02 Desember 2014; Reza dan Bowo, Anggota Tim Audit, W awancara, Surabaya, 02 D esember 2014. 
debitur, apakah debitur yang didapat SA atau AO benarbenar layak dicairkan pembiayaannya.

4. Pemeriksaan atas kesesuaian yang tertera saat kesepakatan (akad)

Audit internal pembiayaan memeriksa debitur apakah debitur menerima dan mengalokasikan dana pembiayaan sesuai dengan kesepakatannya dengan bank, misalnya pembiayaan untuk modal kerja tidak digunakan untuk kebutuhan konsumtif. Hal ini juga berkaitan dengan pemeriksaan kepatuhan auditee dalam monitoring pembiayaan.

5. Pemeriksaan atas monitoring

Audit internal pembiayaan memeriksa apakah bank telah melakukan monitoring pasca pencairan pembiayaan, terutama pada pembiayaan modal kerja (mud)a $>$ rabah dan musha>rakah) agar lebih jelas pembagian nisbahnya. ${ }^{30}$

Berdasarkan kegiatan audit internal dalam pemeriksaan prosedur pembiayaan tersebut di atas, maka audit internal berperan dalam pengendalian risiko pembiayaan Bank BRI Syariah Kantor Cabang Diponegoro Surabaya dalam bentuk:

1. Pelaksanaan audit internal dapat mendeteksi dan menilai kelemahan/kekurangan terhadap prosedur pembiayaan yang disesuaikan dengan kondisi perusahaan, persaingan bisnis, ataupun hal-hal lain yang sedang berkembang. Di antara kelemahan yang ditemukan auditor atas prosedur pembiayaan yang dilakukan auditee tercantum dalam laporan hasil auditnya.

2. Adanya audit internal pembiayaan dapat meningkatkan kualitas pemberian pembiayaan ataupun kebenaran informasi tentang penyaluran pembiayaan yang dibutuhkan manajemen bank. Sebagaimana dalam tabel 3.2 di atas, informasi yang didapat auditor sangat berguna bagi

\footnotetext{
${ }^{30}$ Made Dharmawan, Anggota Tim Audit,W awancara, Surabaya, 13 N ovember 2014; Ade Irfan, Ketua Tim Audit, Wawancara, Surabaya, 02 Desember 2014; Reza dan Bowo, Anggota Tim Audit, W awancara, Surabaya, 02 D esember 2014.
}

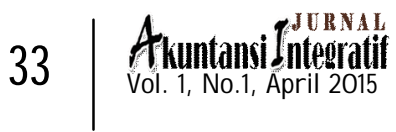


perbaikan dalam kualitas pemberian pembiayaan untuk lebih cermat dan hati-hati

3. Audit internal dapat menilai mitigasi risiko yang telah dilakukan dalam pemberian pembiayaan. Hal ini diperoleh audit berdasarkan data-data proses pencairan pembiayaan kepada nasabah. Sehingga apabila ditemukan pencairan pembiayaan yang mengandung risiko, auditor akan menindaklanjuti dengan mengunjungi nasabah yang bersangkutan.

4. Pemeriksaan audit dapat menjadi penghubung antara unit pembiayaan dengan manajemen selaku pembina sistem melalui usulan yang diberikan oleh bagian audit kepada manajemen berdasarkan fakta-fakta yang ditemukan di lapangan maupun isu hal-hal yang sedang berkembang.

5. Pelaksanaan audit internal dapat mengatasi kelemahan atas pelaksanaan internal control yang ada dalam pemberian pembiayaan. Ketika diperoleh temuan audit berupa pembiayaan berisiko yang disebabkan oleh lemahnya internal control auditee,auditee merasa ditegur atas kesalahannya. Oleh karena itu, auditee diharuskan mengetahui lebih dalam tentang job descriptionnya, Standard Operating Procedure (SOP), peraturan Produk, Jasa dan Hukum Perbankan serta peraturan regulator lainnya seperti Undang-Undang No. 21 tahun 2008 dan Peraturan Perbankan Indonesia (PBI) dalam perbaikan kinerjanya.

Semakin kompeten auditee dalam menindaklanjuti pembiayaan bermasalah atau pembiayaan dalam kolektibilitas tinggi, maka semakin menurunnya tingkat kolektibilitas nasabah menjadi lancar yang berarti pembiayaan bermasalah semakin berkurang. Sehingga secara tidak langsung temuan audit internal dapat menurunkan tingkat kolektibilitas pembiayaan yang tinggi. Hal ini terbukti dengan berkurangnya pembiayaan bermasalah pada tahun 2013 dibanding dua tahun sebelumnya berdasarkan tingkat kolektibilitasnya di Bank 
BRI Syariah Kantor Cabang Diponegoro Surabaya dalam tabel berikut:

Tabel 3.3

Jumlah Pembiayaan Berdasar Kolektibilitas Bank BRI

Syariah KC Diponegoro Surabaya ${ }^{31}$

\begin{tabular}{|c|c|c|c|}
\hline \multirow{2}{*}{ Kolektibilitas } & \multicolumn{3}{|c|}{ Tahun } \\
\cline { 2 - 4 } & 2011 & 2012 & 2013 \\
\hline 1 & 40 & 46 & 51 \\
\hline 2 & 7 & 6 & 4 \\
\hline 3 & 4 & 2 & 1 \\
\hline 4 & 2 & 1 & - \\
\hline 5 & 5 & 5 & 4 \\
\hline
\end{tabular}

Sumber: Data Diolah Berdasarkan Data Pembiayaan Bank BRI Syariah Kantor Cabang Diponegoro Surabaya tahun 2011-2013

Tabel 3.3 menunjukkan semakin berkurangnya pembiayaan yang bermasalah di Bank BRI Syariah Kantor Cabang Diponegoro Surabaya. Berdasar data tersebut tidak dipungkiri adanya pengaruh langsung dari audit yang telah dilakukan Tim Audit Intern. Pengaruh langsung itu berupa treatment terhadap kinerja auditee (Account Officer). Sehingga AO semakin disiplin dalam menjaga efisiensi kolektibitas nasabah

6. Pelaksanaan audit internal juga secara tidak langsung berdampak pada berkurangnya kolusi antara personil bagian pembiayaan dengan debitur/nasabah. Misalnya dengan adanya hubungan dekat antara petugas pembiayaan dengan debitur, petugas pembiayaan dapat mengabulkan permohonan pembiayaan debitur tanpa jaminan yang cukup. Hal ini dapat menimbulkan munculnya pembiayaan macet. Dengan demikian, peran audit internal sangat diperlukan, di mana timResident Auditor Pembiayaan Bank BRI Syariah dapat memeriksa lebih lanjut bukti kelayakan

31 Made Dharmawan, "Kolektibilitas Pembiayaan Bank BRI Syariah", Dokumen Pribadi, Desember 2013.

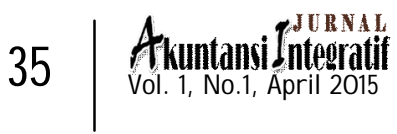


calon debitur pembiayaan. Adanya audit internal pembiayaan dapat meningkatkan kualitas pemberian pembiayaan ataupun kebenaran informasi tentang penyaluran pembiayaan yang dibutuhkan manajemen bank. Karena informasi yang diperoleh auditor dalam pemeriksaannya (temuannya) dapat dijadikan bahan evaluasi auditee terhadap pembiayaan yang disalurkannya

7. Pelaksanaan audit internal dapat menilai ketaatan petugas pembiayaan terhadap prosedur dan kebijakan. Para pegawai dapat lebih patuh dan tidak satupun prosedur yang dilewatkan dalam proses pemberian pembiayaan. Adanya audit internal menjadikan pegawai dapat melakukan pekerjaan dengan baik sesuai prosedur yang ada. ${ }^{32}$

Peranan Audit Internal dalam Pengendalian Risiko Pembiayaan di Bank BRI Syariah Kantor Cabang Diponegoro Surabaya

Analisis peranan audit internal ini dapat diketahui berdasarkan mekanisme kinerjanya dalam pengendalian risiko pembiayaan dengan memeriksa kegiatan penyaluran pembiayaan bank yang diaudit. Pada kegiatan penyaluran pembiayaannya, bank diperiksa dan dievaluasi agar kegiatan tersebut sesuai dengan prosedur sehingga tidak memicu besarnya pembiayaan bermasalah (macet) yang dapat merugikan bank. Berdasar pemahaman ini maka audit internal pembiayaan di Bank BRI Syariah Kantor Cabang Surabaya adalah pihak yang mengawasi dan mengevaluasi kegiatan penyaluran pembiayaan yang dilakukan oleh petugas pembiayaan (auditee) kantor cabang agar sesuai dengan tanggung jawabnya. Tanggung jawab auditee ini tentunya bagaimana ia dalam merealisasi pembiayaan nasabahnya sesuai dengan aturan yang berlaku.

32 Made Dharmawan, Anggota Tim Audit,Wawancara, Surabaya, 30 N ovember 2014; Ade Irfan, Ketua Tim Audit, Wawancara, Surabaya, 02 Desember 2014; Reza dan Bowo, Anggota Tim Audit, Wawancara, Surabaya, 02 D esember 2014.

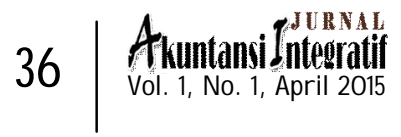


Berdasarkan tugasnya tersebut, audit internal pembiayaan di Bank BRI Syariah Kantor Cabang Surabaya dilaksanakan oleh tim audit kantor cabang yang disebut Resident Auditor (RA). Mekanisme pelaksanaan kegiatan auditnya sebagaimana yang ditetapkan oleh Standar Pelaksanaan Fungsi Audit Intern Bank (SPFAIB) dari Bank Indonesia bahwa mekanisme audit internal meliputi tahap persiapan audit, penyusunan program audit, pelaksanaan penugasan audit, pelaporan hasil audit, tindak lanjut hasil audit dan dokumentasi.

Tahap persiapan audit yang dilakukan berupa pengumpulan data pembiayaan dan dilakukan sampling nasabah berdasarkan risk profile untuk menentukan nasabah/auditee yang akan diaudit. Penulis melihat dalam tahap ini auditor telah menyusun kekeliruan yang terjadi dalam penyaluran pembiayaan oleh auditee. Auditor belum menyusun mitigasi dari risiko pembiayaan yang terjadi seperti dalam bentuk key risk mitigation. Sehingga dalam pelaksanaan audit, auditor tidak mempunyai pedoman mitigasi risiko terlebih dahulu. Mitigasi risiko yang diberikan auditor langsung dicantumkan dalam KKPA dan LHA setelah pemeriksaan.

Pemilihan sampel pembiayaan yang akan diaudit diambil hanya beberapa dari pembiayaan yang mewakili setiap kolektibilitas dan berdasar plafon yang besar. Oleh karena waktu dalam pengauditan oleh audit internal pembiayaan hanya satu bulan dengan terbatasnya SDM auditor dan banyaknya pembiayaan yang disalurkan, maka memang hanya beberapa pembiayaan saja yang selesai diaudit. Pembiayaan selebihnya diaudit pada periode bulan selanjutnya bergantung pada keputusan Direktur Utama.

Tahap penyusunan program audit dilakukan dengan menganalisis permasalahan pembiayaan berdasar data pembiayaan. Penyusunan program audit yang dilakukan auditor Bank BRI Syariah Kantor Cabang Surabaya dilakukan oleh masing-masing auditor, tanpa ada ketentuan baku dari

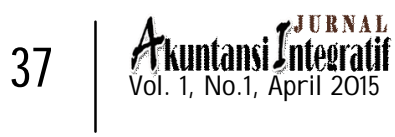


Kantor Pusat. Di sini auditor hanya menyusun catatan kecil pribadi tentang program pengauditan yang akan dilaksanakan.

Pada tahap pelaksanaan audit yang merupakan ciri khas kegiatan audit berupa memeriksa keakuratan data dengan kunjungan langsung pada nasabah sehingga diperoleh temuantemuan audit. Made Dharmawan menyebutkan dalam proses ini diperlukan mental dan kepekaan sebagai auditor dalam menghadapi situasi dan kondisi nasabah pembiayaan yang berisiko. Karena tidak jarang objek audit ini berada di daerah pelosok. Dalam menggali informasi sehingga ditemukan temuan audit, auditor melakukan wawancara untuk menyesuaikan penuturan keadaan nasabah pembiayaan yang sebenarnya di lapangan dengan data yang dipegang auditor dari auditee. Temuan-temuan audit tersebut dikumpulkan dalam pelaporan hasil audit dalam bentuk Kertas Kerja Pemeriksaan Audit (KKPA) dan Laporan Hasil Audit (LHA).

KKPA dan LHA memuat kondisi nasabah, kelemahan/kesalahan prosedur, kriteria/aturan yang dilanggar, penyebab, dampak, rekomendasi evaluasi dari auditor kepada auditee (bank) serta komentar auditee untuk perbaikan. Rekomendasi evaluasi auditor kepada auditee disampaikan secara tertulis dalam laporannya.

Setelah direview dan ditandatangani Kepala Tim Audit (Kepala RA) dan seluruh tim audit, Laporan Hasil Audit disampaikan kepada Audit Group Head (AGH) Kantor Pusat Bank BRI Syariah, Direktur Utama Bank BRI Syariah. Laporan yang sudah diterima Kantor Pusat dianalisis untuk ditemukan pembiayaan-pembiayaan bermasalah. Pembiayaan bermasalah tersebut perlu ditinjau oleh bank yang diaudit untuk dilakukan perbaikan.

Dalam tindak lanjut hasil audit, menurut Ikatan Bankir Indonesia, semua pihak yang berhubungan dengan operasional perbankan sangat berkepentingan untuk mengetahui, memahami dan memastikan semua temuan berikut permasalahan serta dampak kerugian yang timbul sebagaimana yang tertuang pada temuan hasil audit untuk 
segera diperbaiki sesuai waktu yang ditentukan. Oleh karena itu, Bank BRI Syariah Kantor Pusat mengutus Tim Pencari Fakta (TPF) sebagai tindak lanjut hasil audit untuk memberitahukan temuan audit serta klarifikasi laporan audit dengan auditee Bank BRI Syariah Kantor Cabang Diponegoro Surabaya untuk perbaikan.

Setelah diklarifikasi oleh TPF, tindak lanjut hasil audit selanjutnya dilaksanakan oleh auditee dengan melakukan perbaikan untuk menangani pembiayaan-pembiayaan bermasalah yang ditemukan oleh audit internal. Dalam hal ini berarti bahwa auditor di Bank BRI Syariah tidak berhubungan secara langsung dengan auditee dalam pengendalian risiko pembiayaan sebagaimana yang disampaikan Tawaf bahwa auditor mempunyai peran sebagai pemecah konflik dengan auditee. Adanya audit internal dalam pembiayaan hanya bersifat mengidentifikasi adanya pembiayaan yang berisiko merugikan bank sebagai rujukan auditee melaksanakan kepatuhan dan manajemen risiko bank sebagai tempat kerjanya.

Bank BRI Syariah Kantor Cabang Diponegoro Surabaya sebagai tahap akhir mekanisme audit internalnya, mendokumentasikan dan mengadministrasikan semua proses kegiatan audit mulai dari perencanaan, bukti-bukti temuan hingga laporan dan evaluasi sebagaimana aturan dalam Standar Pelaksanaan Fungsi Audit Intern Bank.33

Berdasarkan mekanisme kinerja audit internal pembiayaan dalam rangka mengevaluasi pembiayaan yang disalurkan tersebut di atas, maka dapat disimpulkan bahwa audit internal mempunyai peran-peran dalam mengendalikan risiko pembiayaan. Masalah yang dihadapi audit internal perbankan berkaitan dengan risiko pada kegiatan operasional bank.

\footnotetext{
${ }^{33}$ Made Dharmawan, Anggota Tim Audit,Wawancara, Surabaya, 13 N ovember 2014; Ade Irfan, Ketua Tim Audit, Wawancara, Surabaya, 02 Desember 2014; Reza dan Bowo, Anggota Tim Audit, Wawancara, Surabaya, 02 Desember 2014; Ikatan Bankir Indonesia, Memahami Bisnis Bank Syariah, 381; dan Tjukria P. Tawaf, Audit Intern Bank: Penelaahan serta petunjuk pelaksanaannya, 16.
}

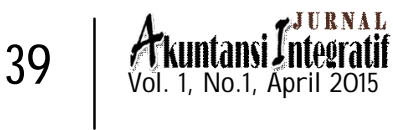


Sedangkan kegiatan operasional bank yang mempunyai risiko yang paling krusial adalah pembiayaan. Risiko pada pembiayaan di Bank BRI Syariah Kantor Cabang Diponegoro Surabaya dapat disebabkan oleh prosedur penyaluran pembiayaan yang tidak tepat. Sehingga akan menimbulkan pembiayaan-pembiayaan yang bermasalah yang ditunjukkan dengan semakin naiknya prosentase NPF.34

Prosentase pembiayaan bermasalah (NPF) di Bank BRI Syariah Kantor Cabang Diponegoro Surabaya pada tahun 2013 semakin berkurang dibanding dua tahun sebelumnya. Hal ini sesuai dengan jumlah pembiayaan berdasarkan kolektibilitas yang tinggi semakin rendah pada tahun yang sama (tabel 3.3). Adapun kondisi NPF Bank BRI Syariah Kantor Cabang Diponegoro Surabaya dari tahun 2011-2013 terlihat dalam tabel di bawah ini:

Tabel 4.1

Outstanding dan NPF Bank BRI Syariah Kantor Cabang Diponegoro Surabaya Tahun 2011-201335

\begin{tabular}{|c|c|c|c|c|}
\hline Tahun & OS & $\%$ & NPF & $\%$ \\
\hline 2011 & 6.814 .497 .552 & $20 \%$ & 898.842 .316 & $13 \%$ \\
\hline 2012 & 10.254 .765 .887 & $34 \%$ & 749.954 .783 & $7 \%$ \\
\hline 2013 & 26.370 .410 .732 & $46 \%$ & 1.127 .825 .883 & $5 \%$ \\
\hline
\end{tabular}

Sumber: Data Diolah dari Outstanding dan NPF Bank BRI Syariah Kantor Cabang Surabaya (2013)

Berdasarkan Tabel 4.1 yang diperoleh peneliti pada bank BRI Syariah Kantor Cabang Diponegoro Surabaya menunjukkan bahwa selama tiga tahun terakhir terjadi penurunan tingkat NPF yang sangat signifikan itu artinya audit memiliki peran yang besar dalam memperbaiki kinerja dalam

\footnotetext{
${ }^{34}$ Tariqullah Khan dan Habib Ahmed, Manajemen Risiko Lembaga Keuangan Syariah, 12; Bambang Rianto Rustam, Manajemen Risiko Perbankan Syariah di Indonesia, 55; dan Made D harmawan, Anggota Tim Audit, W awancara, Surabaya, 13 N ovember 2014

${ }^{35}$ Made Dharmawan, "O utstanding dan N PF Bank BRI Syariah Kantor Cabang Surabaya", D okumen Pribadi, D esember 2013
} 
perbankan. Karena dari temuan audit yang berupa pembiayaan bermasalah akan disampaikan oleh TPF kepada auditee untuk segera melakukan penanganan agar NPF menurun.

Berdasarkan fungsi dan tanggung jawabnya, audit internal untuk pembiayaan di Bank BRI Syariah Kantor Cabang Diponegoro Surabaya yang didasarkan pada program audit, dapat mencerminkan pengendalian risiko pembiayaan. Pelaksanaan audit dapat melihat sampai sejauh mana audit yang dilakukan dapat berperan dalam mengendalikan risiko pembiayaan. Melihat uraian pada bab sebelumnya, maka dapat disimpulkan peran Tim Audit Internal (Resident Auditor) di Bank BRI Syariah Kantor Cabang Surabaya dalam mengendalikan risiko pembiayaan antara lain:

1. Peran Pemecah Masalah

Audit internal seringkali dikatakan sebagai penemu masalah. Dalam hal ini, Tim audit RA Pembiayaan telah menemukan bukti-bukti penyelewengan pembiayaan dalam kunjungannya ke nasabah yang diantaranya berupa side streaming, overfinancing, agunan yang tidak marketable bankable, penyalahgunaan penggunaan dana yang tidak sesuai dalam permohonan pembiayaannya dan lain-lain.

Berdasarkan hasil audit dalam laporannya, tim audit RA Pembiayaan dapat berperan dalam mengurangi kecurangan penyaluran pembiayaan seperti kolusi antara petugas pembiayaan dengan nasabah. Sehingga sesuai dengan tujuan audit itu sendiri dapat membantu petugas pembiayaan melaksanakan tanggung jawabnya secara efektif. ${ }^{36}$ Permasalahan dalam pembiayaan yang ditemukan audit menjadi acuan baik auditee, manajemen bank kantor cabang maupun kantor pusat untuk dievaluasi dan ditindaklanjuti serta dicarikan mitigasi risiko agar permasalahan dalam pembiayaan tersebut tidak terjadi lagi.

${ }^{36}$ Tjukria P. Tawaf, Audit Intern Bank: Penelaahan serta Petunjuk Pelaksanaannya,102; Made D harmawan, "Laporan Hasil Audit (LHA) Bidang Pembiayaan", D okumen Pribadi, D esember 2013

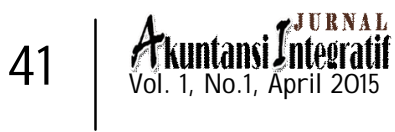




\section{Peran Kepatuhan}

Audit internal merupakan kategori audit kepatuhan, yaitu audit yang tujuannya untuk menentukan apakah yang diaudit sesuai dengan kondisi atau peraturan tertentu. Peran ini dilakukan Tim RA Pembiayaan dengan menilai ketaatan para petugas pembiayaan terhadap prosedur yang telah ditetapkan. Tim audit telah melakukan pemeriksaan data dan bukti-bukti apakah bank telah melaksanakan penyaluran pembiayaannya secara benar. Terbukti ketika pemeriksaan dilakukan, ternyata masih ditemukan kesalahan proses penyaluran dan kurangnya monitoring petugas pembiayaan.

Tim audit RA Pembiayaan juga melakukan audit terhadap kebenaran dokumen-dokumen dan laporan penyaluran pembiayaan dengan cara menyesuaikan data penyaluran pembiayaan dengan prosedur yang benar. Apabila ditemukan kejanggalan atas data/persyaratan nasabah dalam penerimaan pembiayaannya, auditor akan melakukan kunjungan langsung kepada nasabah. ${ }^{37}$

3. Peran Negosiator

Dalam peran negosiator, auditor dituntut untuk terus menerus mampu menjual "posisi auditor", program auditor ataupun ide-ide. Negosiator harus berpegang pada sasaran dan berupaya mendapat hasil yang positif dalam setiap proses sesulit apapun kondisinya. Negosiator yang dimaksud penulis di sini merupakan peran auditor yang menjadi penghubung antara unit pembiayaan dengan manajemen selaku pembina sistem melalui usulan yang diberikan oleh bagian audit kepada manajemen berdasarkan fakta-fakta yang ditemukan di lapangan maupun isu/hal-hal yang sedang berkembang di masyarakat. Sehingga dengan peran negosiator ini para petinggi bank dapat mengetahui kinerja dan operasional bank di bawah pimpinannya yang

${ }^{37}$ Mulyadi, Auditing, 32; Made Dharmawan, Anggota Tim Audit,W awancara, Surabaya, 13 N ovember 2014; Ade Irfan, Ketua Tim Audit, W awancara, Surabaya, 02 Desember 2014; Reza dan Bowo, Anggota T im Audit, W awancara, Surabaya, 02 D esember 2014.

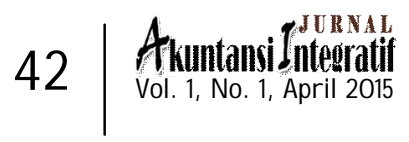


sebenarnya. Hal ini dapat dijadikan pertimbangan dalam berbagai keperluan pengambilan keputusan manajemen bank secara lini maupun terpusat. ${ }^{38}$

4. Peran Pengendalian

Audit internal dalam posisinya menjalankan fungsi SKAI ikut berkepentingan dalam menyelenggarakan Sistem Pengendalian Internal yang handal dan efektif. Berdasarkan pelaporan auditor, audit internal menilai mitigasi risiko yang telah dilakukan dalam pemberian pembiayaan. Hal ini dilakukan untuk mengatasi kelemahan atas pelaksanaan internal control yang ada dalam pemberian pembiayaan. Kinerja auditor dalam inspeksi pembiayaan yang disalurkan auditee menggambarkan bahwa audit internal melakukan internal control untuk pengendalian risiko bagi bank yang diaudit dengan terlebih dahulu menemukan masalahmasalahnya. ${ }^{39}$

Kesemua peran yang diberikan audit internal dapat mengendalikan risiko pembiayaan pada Bank BRI Syariah Kantor Cabang Surabaya dengan hasil riil berupa penurunan tingkat NPF dan penurunan jumlah pembiayaan kolektibilitas tinggi. Di mana hal ini juga menunjukkan adanya upaya auditee memperbaiki kinerjanya sehingga kondisi bank semakin sehat.

\section{Kesimpulan}

Mekanisme yang dilakukan audit internal dalam mengendalikan risiko pembiayaan di Bank BRI Syariah Kantor Cabang Diponegoro Surabaya yaitu dengan melakukan tahapan-tahapan dari proses identifikasi prosedur penyaluran

\footnotetext{
${ }^{38}$ Tjukria P. Tawaf, Audit Intern Bank: Penelaahan serta Petunjuk Pelaksanaannya,103; Made Dharmawan, Anggota Tim Audit,Wawancara, Surabaya, 13 November 2014; Ade Irfan, Ketua Tim Audit, Wawancara, Surabaya, 02 D esember 2014; Reza dan Bowo, Anggota Tim Audit, Wawancara, Surabaya, 02 D esember 2014.

${ }^{39}$ Made Dharmawan, "Piagam Audit (Audit Charter)", D okumen Pribadi, Desember 2009; Made Dharmawan, Anggota Tim Audit,Wawancara, Surabaya, 13 November 2014; Ade Irfan, Ketua Tim Audit, Wawancara, Surabaya, 02 Desember 2014; Reza dan Bowo, Anggota Tim Audit, Wawancara, Surabaya, 02 D esember 2014.
}

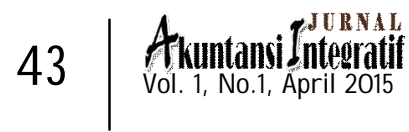


pembiayaan hingga pembuatan laporan hasil audit yang sangat berguna bagi petugas bank dalam evaluasi kinerjanya. Tahapan-tahapan tersebut meliputi tahap persiapan audit yang merupakan langkah awal dalam menemukan pembiayaan yang akan diaudit terlebih dahulu dengan melihat risk profilenya. Tahap kedua yaitu penyusunan program audit, di mana dalam tahap ini auditor menentukan langkah-langkah pemeriksaan. Tahap ketiga yaitu tahap pelaksanaan penugasan audit yang meliputi pemeriksaan seluruh dokumen-dokumen yang berkaitan dengan pemberian pembiayaan mulai dari tahap permohonan hingga monitoring, pengumpulan bukti dan informasi yang cukup kompeten dan relevan berupa semua data dan informasi yang dapat dipakai auditor untuk mendukung temuan auditnya.

Adapun tahap keempat yaitu pelaporan hasil audit dengan membuat Kertas Kerja Pelaksanaan Audit (KKPA) yang isinya temuan-temuan audit berupa kondisi nasabah, kelemahan/kesalahan prosedur, kriteria/aturan yang dilanggar, penyebab, dampak, rekomendasi evaluasi dari auditor kepada auditee (bank) serta komentar auditee untuk perbaikan. Hasil akhir pelaporan audit adalah membuat Laporan Hasil Audit (LHA) yang merupakan kumpulan KKPA dan telah diklarifikasikan dengan auditee bank. Tahap kelima yaitu tindak lanjut hasil audit yang dilakukan oleh TPF (Tim Pencari Fakta), di mana tugasnya adalah klarifikasi temuan audit dengan auditee. Sedangkan tahap keenam atau terakhir yaitu dokumentasi dan administrasi seluruh file temuan audit hingga pelaporannya.

Adapun peran yang ditunjukkan oleh audit internal pembiayaan dalam mengendalikan risiko pembiayaan meliputi peran pemecah masalah, peran kepatuhan, peran negosiator dan peran pengendalian. Peran pemecah masalah ditunjukkan dengan dapat menemukan bukti-bukti penyelewengan/masalah dalam penyaluran pembiayaan dalam kunjungannya ke nasabah yang kemudian diperbaiki agar masalah pada pembiayaan tidak terjadi lagi.

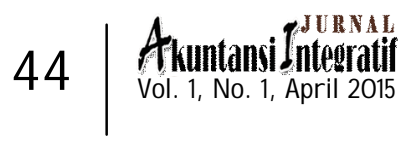


Peran kepatuhan ditunjukkan dengan adanya audit internal dapat meningkatkan ketaatan para petugas pembiayaan terhadap prosedur yang telah ditetapkan dan membuktikan kebenaran dokumen-dokumen dan laporan penyaluran pembiayaan dengan cara menyesuaikan data penyaluran pembiayaan dengan prosedur yang benar.

Adapun peran negosiator yaitu peran audit internal sebagai penghubung antara unit pembiayaan dengan manajemen selaku pembina sistem melalui usulan yang diberikan oleh bagian audit sebagai pertimbangan dalam berbagai keperluan pengambilan keputusan manajemen bank secara lini maupun terpusat. Sedangkan peran pengendalian berupa kinerja auditor dalam inspeksi pembiayaan yang disalurkan auditee menggambarkan bahwa audit internal melakukan internal control untuk pengendalian risiko bagi bank yang diaudit dengan terlebih dahulu menemukan masalah-masalahnya.

\section{Daftar Pustaka}

Djamil, Faturrahman. Penyelesaian Pembiayaan Bermasalah di Bank Syariah. Jakarta: Sinar Grafika, 2012.

Ikatan Bankir Indonesia. Memahami Bisnis Bank Syariah. Jakarta: PT Gramedia Pustaka, 2014.

Karim, Adiwarman A. Bank Islam: Analisis Fiqih dan Keuangan. Jakarta: PT RajaGrafindo Persada, 2011.

Khan, Tariqullah dan Habib Ahmed. Manajemen Risiko Lembaga Keuangan Syariah. Jakarta: Bumi Aksara, 2008.

Muljono, Teguh Pudjo. Bank Auditing: Petunjuk Pemeriksaan Intern Bank. Jakarta: Djambatan, 1999.

Mulyadi. Auditing. Jakarta: Salemba Empat, 2014.

Rivai, Veithzal dan Arviyan Arifin. Islamic Banking. Jakarta: Bumi Aksara, 2010.

Tawaf, Tjukria P. Audit Intern Bank: Penelaahan serta Petunjuk Pelaksanaannya. Jakarta: Salemba Empat, 1999.

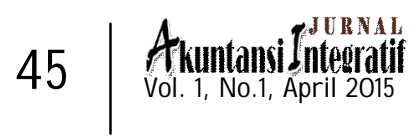


Tugiman, Hiro. Standar Profesional Audit Internal. Yogyakarta: PT Kanikus, 2014.

Dharmawan, Made, "Kolektibilitas Pembiayaan Bank BRI Syariah", Dokumen Pribadi, Desember 2013. , "Kertas Kerja Pemeriksaan Auditor (KKPA) Bidang Pembiayaan", Dokumen Pribadi, Desember 2013. ,"Laporan Hasil Audit (LHA) Bidang Pembiayaan", Dokumen Pribadi, Desember 2013. "Pembiayaan Bank BRI Syariah Kantor Cabang Diponegoro Surabaya", Dokumen Pribadi, Desember 2013. Undang-Undang Republik Indonesia Nomor 6 Tahun 2009 tentang Bank Indonesia dan Undang-Undang Republik Indonesia Nomor 21 Tahun 2008 tentang Perbankan Syariah. Bandung: Citra Umbara, 2013.

BRI Syariah. "Satuan Kerja Audit Internal (SKAI)". Piagam Audit (Audit Charter). Desember, 2009.

BRI Syariah, "Laporan Tahunan 2013", dalam http:/www.brisyariah.co.id/sites/default/files/aporantahu nan/Laporan\%20Tahunan\%202013.pdf, "diakses pada" 31 Oktober 2014.

Otoritas Jasa Keuangan, "OJK-Pedia", dalam http://www.ojk.go.id/pedia\#tabK, diakses pada 11 Desember 2014. 